\title{
36. BACTERIAL PROFILES IN AMAZON FAN SEDIMENTS, SITES 934 AND $940^{1}$
}

\author{
B.A. Cragg, ${ }^{2}$ K.M. Law, ${ }^{2}$ A. Cramp,${ }^{3}$ and R.J. Parkes ${ }^{2}$
}

\begin{abstract}
Bacterial populations were quantified at two Ocean Drilling Program (ODP) Leg 155 sites in the Amazon Fan system to depths of 108 and 245 meters below seafloor (mbsf) in water depths of $\sim 3400$ and $3200 \mathrm{~m}$, respectively. Bacteria were present in all samples, and populations decreased gradually with depth. However, divided/dividing cells were absent in some samples below $70 \mathrm{mbsf}$. Sediment accumulation rates in the Amazon Fan periodically have been very rapid (to $25 \mathrm{~m} / \mathrm{k}$.y.), and the structure of the sediment at both sites was dominated by turbidites, debris flows, and levee slumps. Bacterial profiles at both sites indicated that bacterial populations could be related to changes in the lithostratigraphy. Zones of frequent, small turbidites coupled with bioturbation and zones of massive mud flows or slumps were generally associated with unusually constant bacterial profiles. Conversely, outside these zones where sedimentary input was more dominated by material from the water column, the expected gradual decrease in bacterial populations with depth was observed. A particularly striking change was a strongly positive increase $(\times 3.7)$ of bacterial numbers $(P<0.001)$ coincident with sediment layers rich in plant remains and wood fragments between 17 and $26 \mathrm{mbsf}$ at Site 934. Despite this, the overall profiles conformed to a bacterial depth distribution derived from other ODP sites (exclusively from the Pacific Ocean) indicating that deep bacterial populations are characteristic of all marine sediment. A few tens of centimeters of sediment have accumulated since the fan has been inactive, and near-surface bacterial populations $\left(5.6-6.0 \times 10^{8}\right.$ cells $\left./ \mathrm{cm}^{3}\right)$ are consistent with a trend in near-surface populations with varying water depth observed at Pacific Ocean sites.
\end{abstract}

\section{INTRODUCTION}

Recent Ocean Drilling Program (ODP) research on marine sediments (Whelan et al., 1986; Tarafa et al., 1987; Parkes et al., 1990, 1994; Cragg, 1994; Cragg and Parkes, 1994; Cragg and Kemp, 1995; Cragg et al., 1990, 1992, 1995a, 1995b) has confirmed the presence of a deep bacterial biosphere in marine sediments. Previously, this had only been predicted from the extensive amount of indirect geochemical evidence, that is, chemical changes in pore water, gas production, kerogen modification, concretion formation, and isotopic evidence (Krumbein, 1983; Suess and Whiticar, 1989; Kvenvolden and Kastner, 1990; Kastner et al., 1991). The thermal gradient of the Earth's crust is $\sim 10^{\circ}-40^{\circ} \mathrm{C} / \mathrm{km}$, therefore, in most sediments temperature is unlikely to inhibit bacterial activity until several kilometers below the seafloor as hyperthermophilic bacteria may grow in excess of $110^{\circ} \mathrm{C}$ (Huber et al., 1989; Pledger and Baross, 1991; Jørgensen et al., 1992). Deep sediment bacterial populations decrease exponentially with depth (Parkes et al., 1994) and have been shown to be responsive to deep geochemical changes in the sediment, such as brine incursions (Cragg et al., 1990; Parkes et al., 1990) and the presence of methane and hydrogen sulfide gas hydrates (Cragg et al., 1995b; 1996). Additionally, bacterial sulfate reduction and methanogenic activity has been measured in sediments from depths greater than 500 mbsf (Cragg et al., 1992; Getliff et al., 1992; Parkes et al., 1995).

Submarine fans form the largest deep-water sediment bodies on continental margins (Flood, Piper, Klaus, et al., 1995), and the Amazon Fan is one of the largest modern submarine fans containing much of the material eroded from the Amazon drainage basin in the form of muds and silts. The fan has been active during glacial periods with

${ }^{1}$ Flood, R.D., Piper, D.J.W., Klaus, A., and Peterson, L.C. (Eds.), 1997. Proc. ODP, Sci. Results, 155: College Station, TX (Ocean Drilling Program).

${ }^{2}$ Department of Geology, University of Bristol, Bristol BS8 1RJ, United Kingdom. b.cragg@bristol.ac.uk

${ }^{3}$ Department of Earth Sciences, University of Wales, Cardiff, P.O. Box 914, Cardiff, CF1 3YE, United Kingdom. the production of a number of channel and levee systems with sediment deposition rates of $1-25 \mathrm{~m} / \mathrm{k} . \mathrm{y}$., but during interglacials sediment has accumulated much more slowly at $<0.1 \mathrm{~m} / \mathrm{k} . \mathrm{y}$. These rates compare to $\sim 4 \mathrm{~m} / \mathrm{k}$.y. in the Santa Barbara Basin (Schimmelmann et al., 1990), which is regarded as a particularly high sedimentation rate.

The depositional history of the Amazon Fan is further complicated by the occurrence of very large numbers of turbidites, debris flows, and levee slumps (Damuth and Flood, 1984, 1985). On many occasions, organic-carbon-rich surface sediments have been buried by subsurface sediment particles of relatively low organic carbon concentration, but with pore spaces replenished with sulfate. To our knowledge, this is the first investigation of deep bacterial populations in a submarine fan, a system that is dominated by sediment flow rather than depositional processes.

\section{MATERIALS AND METHODS Site Description}

Sites 934 and 940 are located on the Amazon Fan off northeast Brazil (Fig. 1). Site $934\left(5^{\circ} 29.047^{\prime} \mathrm{N}, 47^{\circ} 40.857^{\prime} \mathrm{W}\right)$ is located in a cutoff meander bend of the main Amazon Channel of the Amazon Fan (Flood, Piper, Klaus, et al., 1995) in a water depth of $3432 \mathrm{~m}$. Substantial sections recovered at this site are interpreted as overbank spillover from turbidity currents, muddy slump deposits, and sandy debris flows. The current seafloor of the meander is $55 \mathrm{~m}$ higher than the main seafloor, resulting from sedimentation in the abandoned meander bend and possibly from incision from the main channel after cutoff. The geothermal gradient at this site was estimated at $35^{\circ} \mathrm{C} /$ $\mathrm{km}$. Site $940\left(5^{\circ} 8.569^{\prime} \mathrm{N}, 47^{\circ} 31.728^{\prime} \mathrm{W}\right)$ is located on the flank of the eastern levee of the Amazon Channel in the uppermost middle fan at a present-day water depth of 3195 m (Flood, Piper, Klaus, et al., 1995). This site is located close to two avulsion points that may correlate with rapid growth phases of the levee. A number of slump deposits were recovered at this site. The geothermal gradient here was estimated at $29^{\circ} \mathrm{C} / \mathrm{km}$. Sedimentation rates across the Amazon Fan 


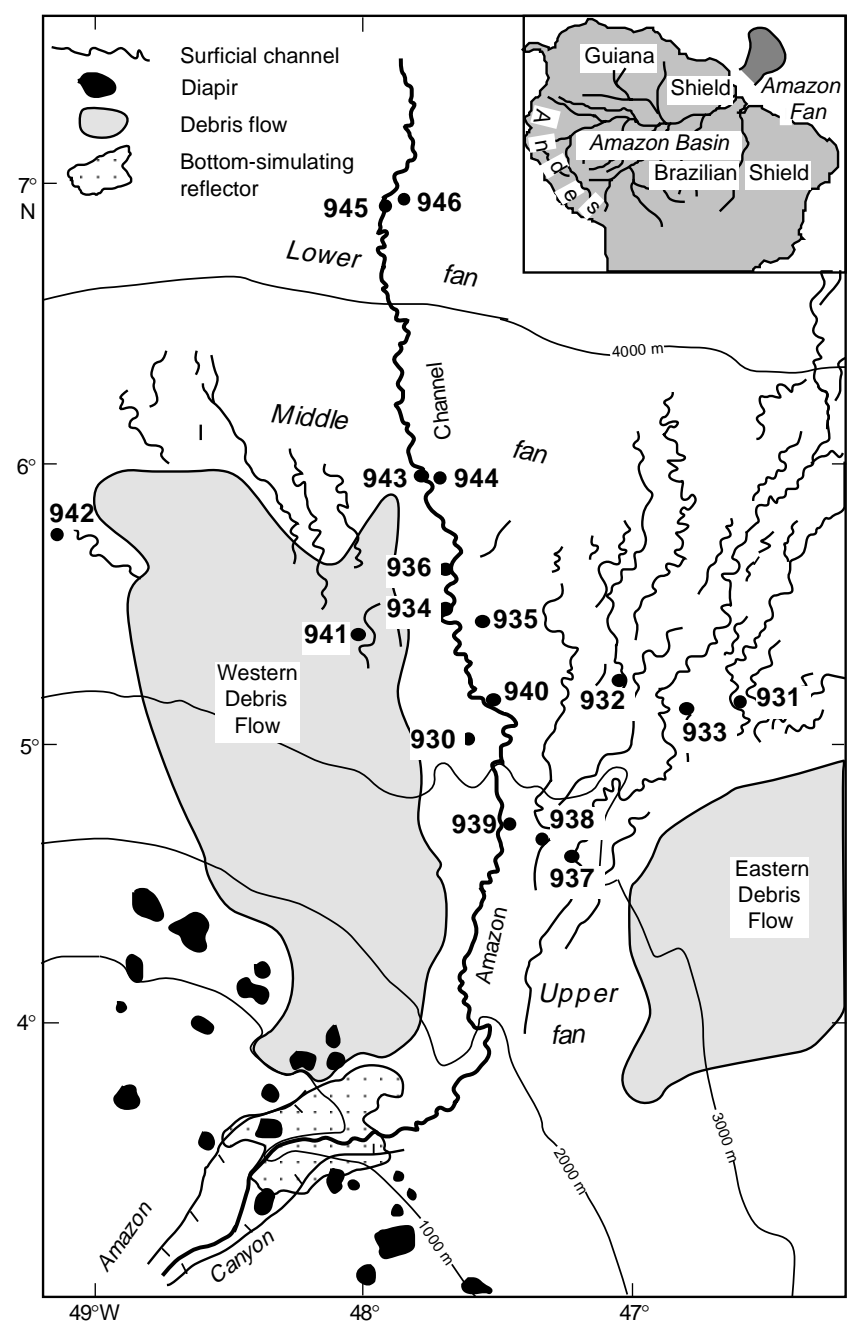

Figure 1. Map of the Amazon Fan showing location of ODP sites in relation to surficial channel systems and debris flows. From Flood, et al., (1995); modified from Damuth et al. (1988) and Manley and Flood (1988).

vary from $\sim 1-20 \mathrm{~m} / \mathrm{k}$.y. during low sea-level stands to $1 \mathrm{~cm} / \mathrm{k} . y$. during periods of high sea level when more riverine-derived sediment is deposited on the continental shelf (Damuth and Kumar, 1975).

\section{Shipboard Handling}

A series of $19 \times 1-\mathrm{cm}^{3}$ sediment samples were removed from core sections of Hole 934A, between 0 and $108.3 \mathrm{mbsf}$, and $32 \times 1-\mathrm{cm}^{3}$ sediment samples at Hole 940A were taken between 0 and 243.5 mbsf. Immediately after a core was cut into 1.5 -m sections on the outside catwalk, a thin layer of sediment was removed from the section end using a sterile scalpel to expose an uncontaminated surface. A 1$\mathrm{cm}^{3}$ sample was then taken with a sterile (autoclaved) 5-mL syringe from which the leur end had been removed. The sample was ejected directly into a tared serum vial containing $9 \mathrm{~mL}$ of filter sterilized $(0.2 \mu \mathrm{m}) 4 \%$ formaldehyde in artificial seawater.

\section{Laboratory Handling}

\section{Direct Microscopic Observations}

Acridine orange staining and microscopic observations were based on the general recommendations of Fry (1988). Fixed samples were vortex mixed, and a $4-$ to $10-\mu \mathrm{L}$ subsample was added to $10 \mathrm{~mL}$ of $2 \%$ filter-sterilized $(0.1 \mu \mathrm{m})$ formaldehyde in artificial seawater. Acridine orange $(50 \mu \mathrm{L})$ was added to give a final concentration of 5 $\mathrm{mg} / \mathrm{dm}^{3}$. After $3 \mathrm{~min}$ the solution was filtered through a $25-\mathrm{mm} \mathrm{Nu}-$ cleopore black polycarbonate membrane (Costair, High Wycombe, United Kingdom) of $0.2-\mu \mathrm{m}$ pore size. The filter was rinsed with a further $10 \mathrm{~mL}$ of $2 \%$ filter-sterilized formaldehyde in artificial seawater and mounted in a minimum of paraffin oil under a coverslip. Three replicate filters were prepared from each sample to minimize the variance of the counts (Kirchman et al., 1982). Where 95\% confidence limits of the mean count exceeded $0.5 \log _{10}$ units, further replicate filters were prepared. A minimum of 200 fields of view were counted.

The mounted membrane filters were viewed under incident illumination with a Zeiss Axioskop microscope fitted with a 50-W mercury vapor lamp, a wide-band interference filter set for blue excitation, a $100 \times$ (numerical aperture $=1.3$ ) Plan Neofluar objective lens, and $10 \times$ eyepieces. Bacterially shaped green and red fluorescing objects were counted. Cells on or off particles were counted separately, and the numbers of those on particles doubled in the final calculations to account for cells hidden from view by particles (Goulder, 1977). Dividing cells (those with a clear invagination) and divided cells (pairs of cells of identical morphology) were also counted. The detection limit for bacterial cells was calculated to be $1 \times 10^{5}$ cells $/ \mathrm{cm}^{3}$ (Cragg, 1994).

\section{RESULTS AND DISCUSSION}

\section{Site 934}

Total bacterial populations are high in the near-surface sediment at $6.05 \times 10^{8}$ cells $/ \mathrm{cm}^{3}$ (Fig. 2), and decrease rapidly to $3.46 \times 10^{6}$ cells $/ \mathrm{cm}^{3}$ by $108 \mathrm{mbsf}$ (a $175 \times$ decrease), with a minimum of $2.1 \times$ $10^{6}$ cells $/ \mathrm{cm}^{3}$ at $99 \mathrm{mbsf}$. The bacterial population profile for much of the hole generally parallels the general decrease with depth observed for Pacific Ocean sediments (Fig. 2; Parkes et al., 1994). However, between 3 and 69 mbsf, bacterial numbers are consistently and significantly $(P<0.05)$ greater than expected. Between 10.3 and 69 mbsf, the total bacterial population size is surprisingly constant at $1.95 \pm 0.18 \times 10^{7}$ cells $/ \mathrm{cm}^{3}$ (mean and $95 \%$ confidence limits), apart from a highly significant $(P<<0.001)$ increase $(\times 3.7)$ in numbers between 16.8 and $26.3 \mathrm{mbsf}$. This $10.5-\mathrm{m}$ section coincides very closely with a layer rich in plant debris (between 22 and $29 \mathrm{mbsf}$ ) and wood fragments (between 14 and 29 mbsf; Fig. 3). There is a second layer of sediment rich in wood fragments between 62 and 68 mbsf. No samples were taken for bacterial counts in this section, however, and thus no bacterial response was observed. Overall, there is no correlation between bacterial numbers and total organic carbon (TOC), although this may reflect the paucity of TOC data in the upper organiccarbon-rich layer, and the complete absence of microbiological data in the deeper organic carbon-rich layer (Fig. 3). Previous work has demonstrated a significant correlation between total bacterial numbers and sediment organic carbon concentrations (Parkes et al., 1993; Cragg and Kemp, 1995; Cragg et al., 1995a).

The total bacterial numbers strongly correlate $(R=0.965 ; N=16$; $P \ll 0.002$ ) with dividing and divided cell numbers (DDC) that represent $\sim 7 \%$ of the total population (Fig. 2). This relationship has been commonly observed in Pacific Ocean sites (Parkes et al., 1990; Cragg, 1994; Cragg et al., 1992; 1995a, 1995b; Cragg and Parkes, 1994; Cragg and Kemp, 1995). Between 70 mbsf and the last sample at 108 mbsf, DDC were detected only once at 89 mbsf. Over this same depth range, the total bacterial numbers significantly decreased by a factor of $9(t=5.85$; d.f. $=6 ; P<0.002)$ when compared to the four data points immediately higher up in the sediment column (Fig. 2). Nevertheless, our complete inability to detect DDC in three out of the four sub-68 mbsf samples was unexpected, although this may be the result of the particularly low organic carbon concentrations over this depth range (mean $=0.36 \%$, assuming that the high value at 


\section{$\log _{10}$ bacterial numbers (cells/cm³)}

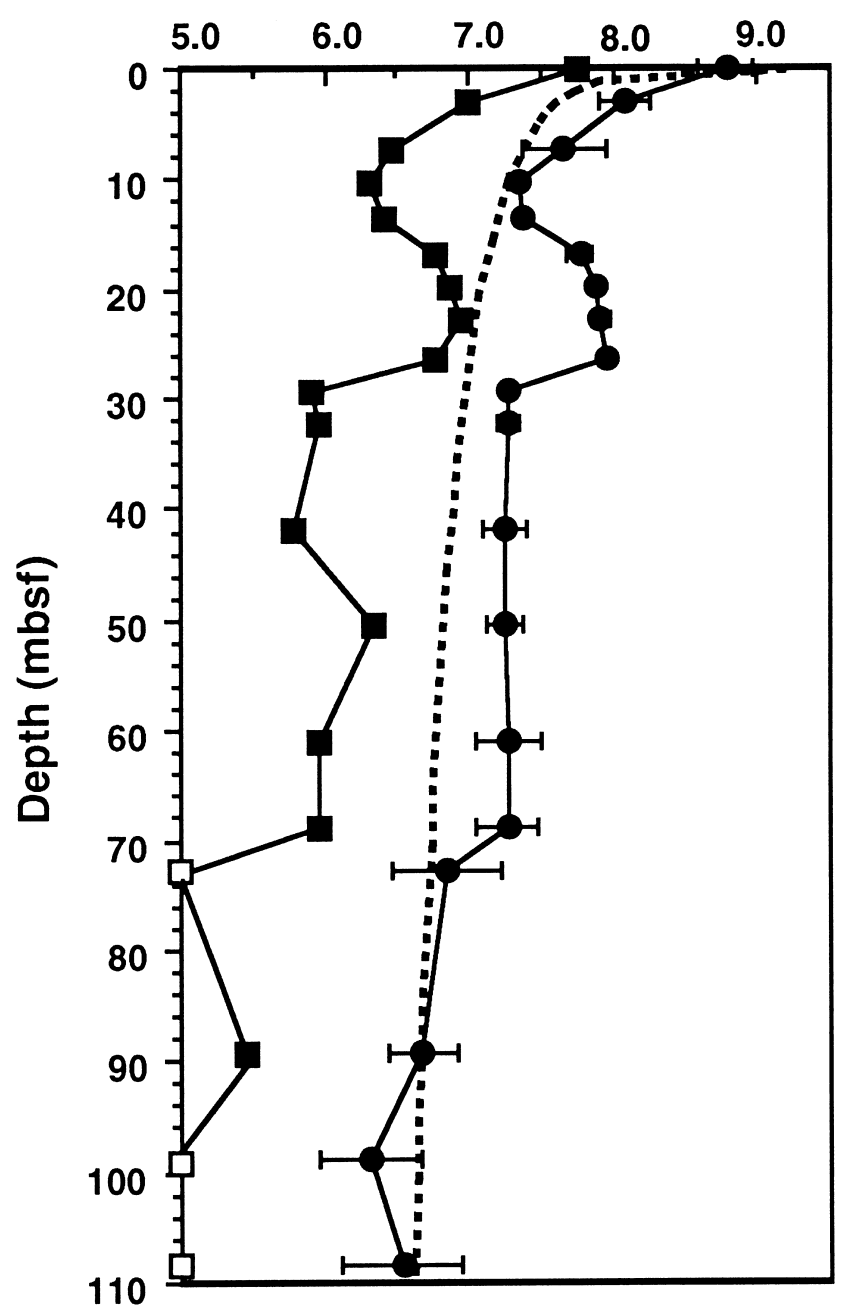

Figure 2. Depth distribution of total bacteria (solid circles) and dividing/ divided cells (solid squares) at Site 934, using the Acridine Orange Direct Count technique. Open symbols represent a zero count at the detection limit of $1 \times 10^{5}$ cells $/ \mathrm{cm}^{3}$. Horizontal lines on the total count symbols are $95 \%$ confidence intervals. The heavy dashed, curved line represents a regression line $(\log$ count $=7.94-0.64 \log$ depth) derived from bacterial depth distributions in Pacific Ocean sediments (Parkes et al., 1994).

108.45 mbsf obtained slightly below the last bacterial count is anomalous). Similar inabilities to detect DDC have been encountered at other sites very low in organic carbon (Cragg, 1994; Cragg and Kemp, 1995). In contrast, above $68 \mathrm{mbsf}$, where organic carbon concentrations were higher $($ mean $=0.93 \%)$, DDC were observed in all samples.

The interstitial water chemistry was relatively simple at this site. Sulfate concentrations of $23.35 \mathrm{mM}$ at $1.45 \mathrm{mbsf}$ decrease to zero by $7.95 \mathrm{mbsf}$ and remain at less than $0.04 \mathrm{mM}$ (Flood, Piper, Klaus, et al., 1995). Most sulfate reduction should therefore occur in the 07.95 mbsf depth range, and this is supported by alkalinity data (Flood, Piper, Klaus, et al., 1995). This depth range also coincides with a higher than expected total bacterial population (Fig. 2).

Methane concentrations were relatively constant with depth (mean $=9460$ ppmv between 21.3 and $103.8 \mathrm{mbsf}$ ), with a near absence at $1.5 \mathrm{mbsf}$ and a large peak occurring at $11.8 \mathrm{mbsf}(55,400$ ppmv; Flood, Piper, Klaus, et al., 1995). This may reflect the usual

\section{$\log _{10}$ Total bacterial numbers (cells $/ \mathrm{cm}^{3}$ )}

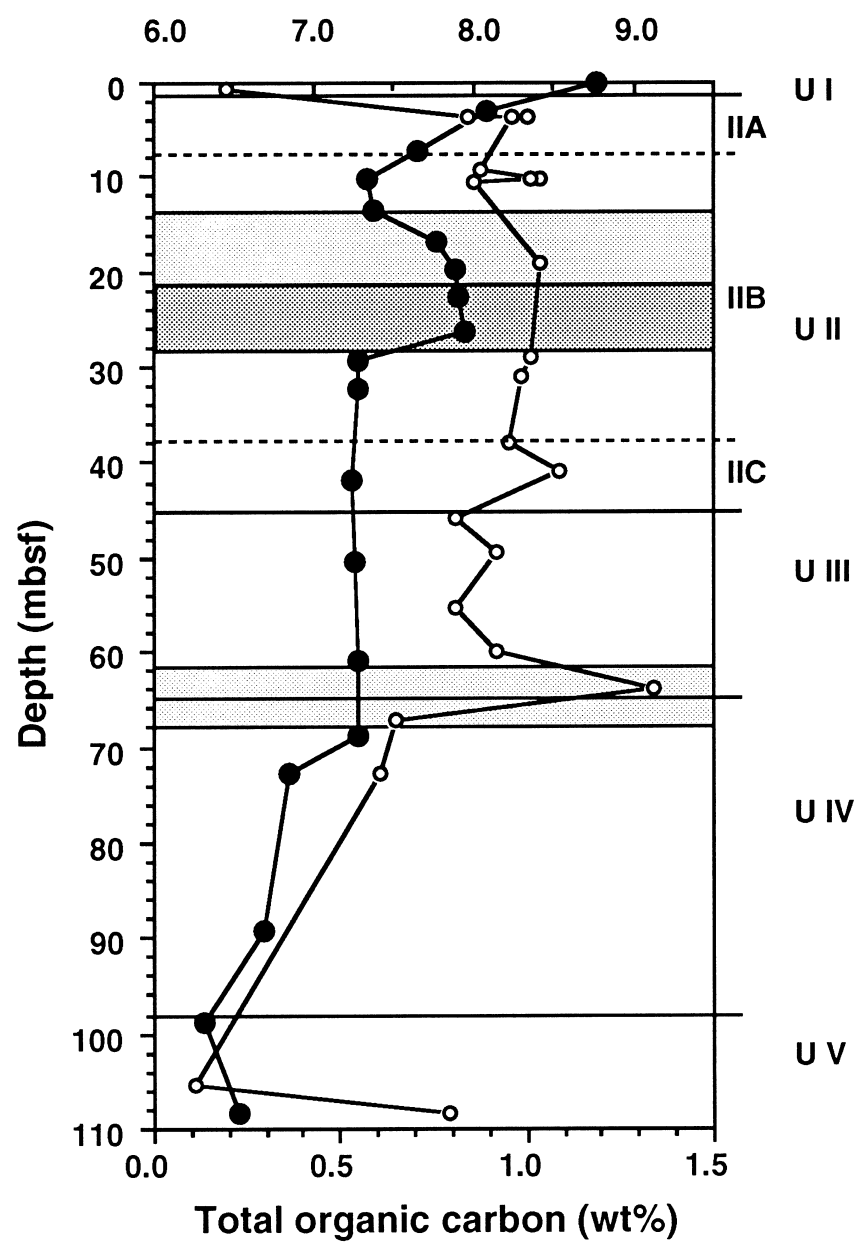

Figure 3. Depth distribution of total bacteria (solid circles) and organic carbon concentrations (small open circles) at Site 934. Horizontal solid lines and dashed lines represent unit and subunit boundaries, respectively. Pale shading indicates zones rich in plant fragments, and dark shading indicates zones rich in wood fragments.

situation of a peak of methane due to local methanogenesis immediately below the zone of sulfate reduction, which ends at $\sim 8 \mathrm{mbsf}$, or alternatively, this may be a result of the migration of bacterially produced methane from lower sediment layers.

The unexpected general constancy of total bacterial numbers between 10.3 and 69 mbsf is difficult to fully understand, as it implies a degree of sediment homogeneity that does not initially seem to be supported by lithostratigraphic analysis. Any attempt at interpreting this must be speculative as this data is derived from only $12 \times 1 \mathrm{~cm}^{3}$ samples taken from a 60-m-deep sediment column; nevertheless, some pertinent observations can be identified. For example, between 30 and 65 mbsf vivianite (hydrated iron phosphate) nodules were recorded as common. This is coincident with an uninterrupted section of uniform bacterial numbers (Fig. 3) and suggests some sediment homogeneity, although this zone covers parts of two different lithostratigraphic units.

Unit III (Fig. 3) consists of a muddy mass flow that has subsequently undergone deformation, plastic folding, injection of sand and mud, and partial mixing (Flood, Piper, Klaus, et al., 1995). Interestingly, there is some uncertainty concerning the exact depth of the base of Unit III (65-70 mbsf). However, if the bacterial numbers can be taken to indicate which unit a particular sediment layer can be at- 
tributed to, then the Unit III/IV transition may occur below the last of the "uniform" counts at 68.95 mbsf. Unit II is interpreted as sediment that filled the abandoned meander bend by spillover from turbidity currents flowing down the main Amazon Channel after the meander was cut off (Flood, Piper, Klaus, et al., 1995). Much of Unit II thus might be expected to be bacteriologically relatively homogeneous. This is the case for Subunits IIC and IIB, although superimposed on this is the local increase in populations due to plant debris. Subunit IIA, however, is not homogeneous as bacterial numbers decrease logarithmically with increasing depth, a trend consistent with near-surface counts in Unit I (Fig. 3). Although Unit IIA does have some inferred mud turbidites, there is a fining-upward trend with hemipelagic laminae above the turbidites, and as this subunit and Unit I are the only units to contain elevated foraminifer concentrations (Flood, Piper, Klaus, et al., 1995), this suggests that a significant component of the sediment in Subunit IIA must be depositional rather than the result of mass flow. This is consistent with the similar trends in bacterial populations within these units and with active sulfate reduction.

\section{Site 940}

The total bacterial population is high in the near-surface sediment at $5.62 \times 10^{8}$ cells $/ \mathrm{cm}^{3}$ (Fig. 4) and is not significantly different $(t=$ 0.27 ; d.f. $=4$ ) from that at Site 934 (Fig. 3). Bacterial numbers decrease rapidly to a minimum of $2.69 \times 10^{6} \mathrm{cells} / \mathrm{cm}^{3}$ at $81.8 \mathrm{mbsf}$ (a $210 \times$ decrease). Between $\sim 67$ and $214 \mathrm{mbsf}$, the bacterial profile remains roughly constant at $5 \times 10^{6}$ cells $/ \mathrm{cm}^{3}$. Below $214 \mathrm{mbsf}$, however, there is a sustained and significant $(P<0.02)$ increase in total bacterial numbers to a maximum of $2.72 \times 10^{7}$ cells $/ \mathrm{cm}^{3}$ (a $5 \times$ increase). The bacterial population profile for much of the hole generally parallels the decrease with depth observed for Pacific Ocean sediments (Fig. 4; Parkes et al., 1994). Two exceptions to this are between 5.8 and $67 \mathrm{mbsf}$ where all of the data, with a single exception, are significantly $(P<0.05)$ above the regression line, and between 221 and $243.5 \mathrm{mbsf}$ when, again, all of the data are significantly $(P<$ 0.01 ) above the regression line (Fig. 4). The former group of data approximately coincides with Subunits IIA-IID, with reversion of the bacterial population sizes to predicted levels occurring across Subunit IIE and the uppermost part of Subunit IIF. The latter group coincides with Subunits IIH-IIJ (Flood, Piper, Klaus, et al., 1995). Subunits IIA-IID (roughly the Amazon levee system) are characterized by cycles of abundant turbidites $(30-60 / \mathrm{m})$ together with moderate bioturbation and color banding. This high frequency of small turbidites combined with bioturbation may well account for the homogeneity of the bacterial counts, particularly the DDC, over this part of the sediment column. The increase in the bacterial population toward the base of this hole will be discussed later.

The total bacterial numbers again strongly correlate $(R=0.929 ; N$ $=32 ; P<<0.002$ ) with DDC numbers that represent $\sim 8.5 \%$ of the total population (Fig. 4). After an initially rapid decline in DDC to 11.8 mbsf, the population remains surprisingly constant at $\sim 3.85 \times 10^{6}$ cells $/ \mathrm{cm}^{3}$ to $54 \mathrm{mbsf}$, coincident with Subunits IIB-IID. Thereafter, there is a rapid decline in the DDC, paralleling that in the total count (Fig.4), to $1.57 \times 10^{5}$ cells $/ \mathrm{cm}^{3}$ (a $25 \times$ decrease) at $81.8 \mathrm{mbsf}$. Between 81.8 and 214.5 mbsf, bacterial numbers vary considerably around an average of $3.5 \times 10^{5} \mathrm{cells} / \mathrm{cm}^{3}$, which includes the only occurrence of a "not detectable" DDC result at 182.6 mbsf. Below 214.5 mbsf, which is the start of Subunit IIH, DDC show a persistent and significant $(P<0.02)$ increase to a peak at $2.22 \times 10^{6} \mathrm{cells} / \mathrm{cm}^{3}$ at 243.5 mbsf. Overall, for both the total count and DDC data in the lower half of the hole, there is a significant $(P<0.01$ and $P<0.002$, respectively) trend of increase occurring from $\sim 180 \mathrm{mbsf}$ (Fig. 4).

Explaining the changes in the bacterial profile from the geochemical data (Flood, Piper, Klaus, et al., 1995) is particularly difficult for this hole. Organic carbon concentrations are relatively low, and more or less constant throughout, at $\sim 0.81 \pm 0.07 \mathrm{wt} \%$ (mean $\pm 95 \%$ confidence limits). Interpretation of the inorganic chemistry is compli-

\section{$\log _{10}$ bacterial numbers (cells/cm³)}

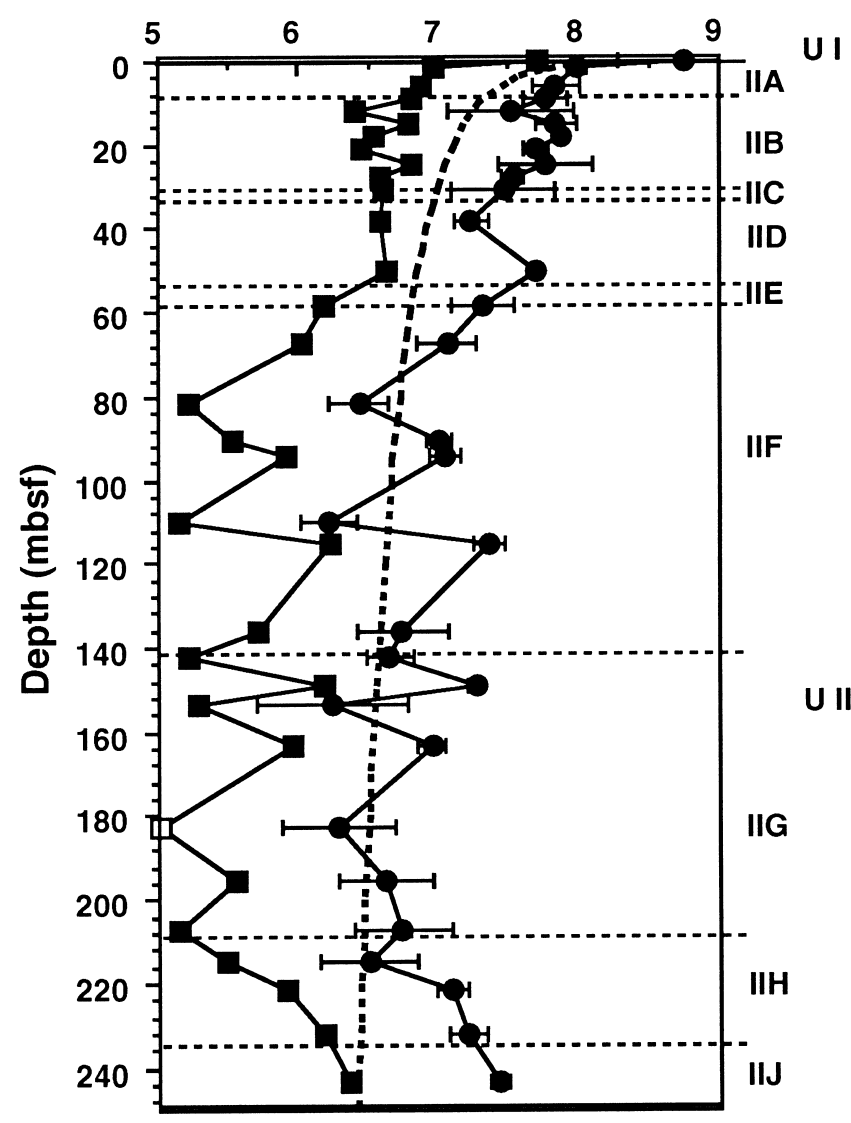

Figure 4. Depth distribution of total bacteria (solid circles) and dividing/ divided cells (solid squares) at Site 940, using the Acridine Orange Direct Count technique. Horizontal solid lines and dashed lines represent unit and subunit boundaries, respectively. See Figure 2 for explanation of other symbols and lines.

cated by the lack of data between 32.55 and $64.2 \mathrm{mbsf}$. No data therefore exist for Subunits IID or IIE, and the Subunit IID/IIE boundary at 55.7 mbsf appears to be bacteriologically important (Fig.4). Consistent with the low organic carbon concentrations at this site (Cragg, 1994; Cragg and Kemp, 1995), pore-water sulfate concentrations do not reach zero until $29.25 \mathrm{mbsf}$, the greatest depth of sulfate penetration encountered on this leg (Flood, Piper, Klaus, et al., 1995). This depth coincided with the maximum methane concentration of nearly $37,000 \mathrm{ppm}$ at $29.3 \mathrm{mbsf}$, and suggests that the situation of bacterially mediated sulfate depletion, followed by an increase in methane concentration usually encountered in the top few meters of marine sediments (Jørgensen et al., 1990), may be occurring to much greater depths because of comparatively low rates of sulfate reduction. Bacterial activity, however, does continue below the sulfate/methane transition albeit at reduced levels as indicated by the high, but decreasing, concentrations of alkalinity and phosphate $(21.62 \mathrm{mM}$ and $71.8 \mu \mathrm{M}$ at $32.55 \mathrm{mbsf}$ and $6.11 \mathrm{mM}$ and $2.3 \mu \mathrm{M}$ at $64.2 \mathrm{mbsf}$, respectively) (Flood, Piper, Klaus, et al., 1995). The lack of any data between these two depths, however, prevents any attempt at correlating the changes in the bacterial profile at $~ 50-60$ mbsf (Fig. 4) with geochemistry.

The significant increase in both total bacterial numbers and DDC below $200 \mathrm{mbsf}$ is surprising. It has been suggested that the high methane concentrations measured over this depth range (an increase from a mean of 9000 to $13,650 \mathrm{ppm}$ ), together with relatively high 


\section{$\log _{10}$ total bacterial numbers $\left(\right.$ cells $\left./ \mathrm{cm}^{3}\right)$}

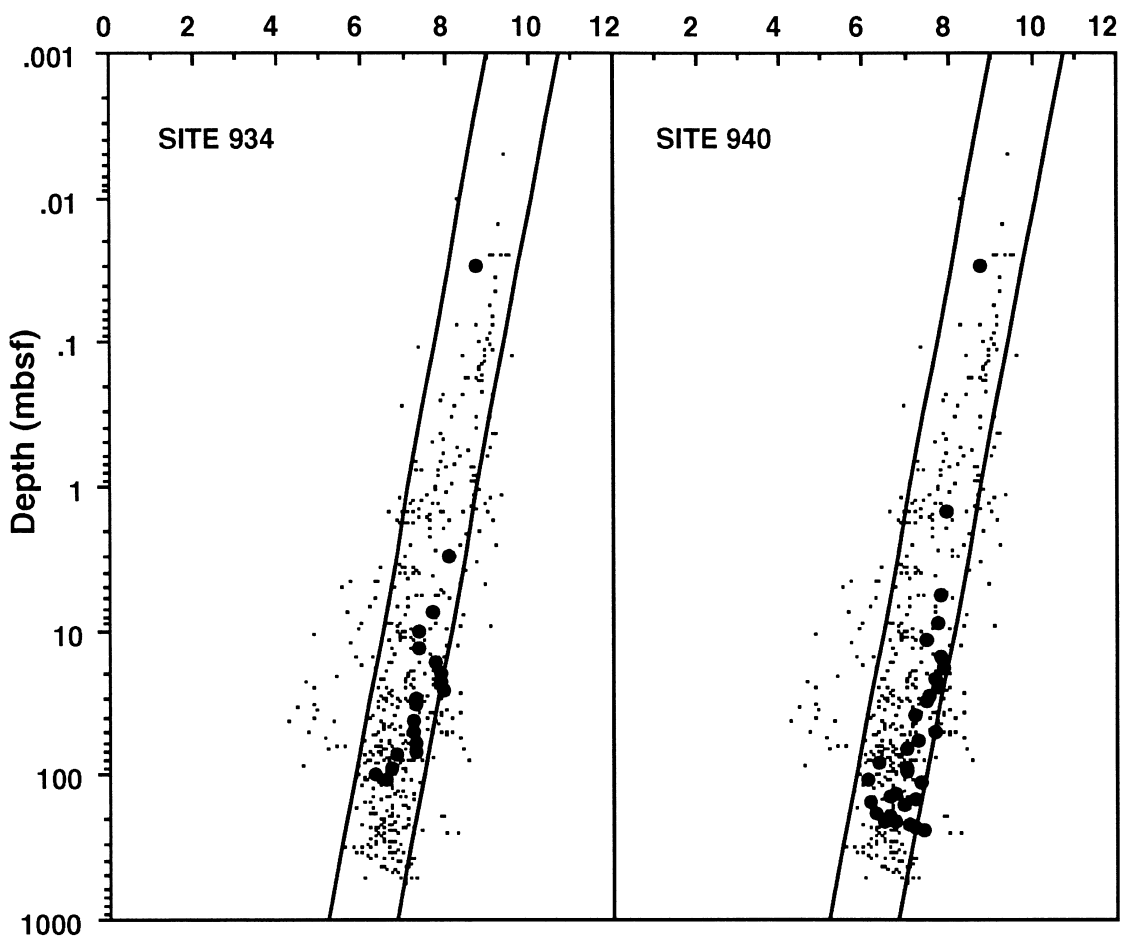

Log total bacterial numbers $=7.94-0.64 \times$ Log depth $(\mathrm{m})$
Figure 5. Depth distribution of total bacteria (solid circles) from Amazon Fan Sites 934 and 940 compared to the distributions of bacterial populations with depth $(n=$ 496) at 13 Pacific Ocean sites from 6 ODP legs (small dots). Heavy slanting lines represent the $95 \%$ prediction limits for the given regression line (Parkes et al., 1994). sulfate concentrations $(1.2-5.3 \mathrm{mM})$, probably indicate that the sulfate was a sampling artifact (Flood, Piper, Klaus, et al., 1995). It is certainly the case that some cores were subject to considerable drilling disturbance, significantly from $190.8 \mathrm{mbsf}$ and particularly from $236.1 \mathrm{mbsf}$. Drilling disturbance, however, is recorded for all cores below 103.9 mbsf. Color banding (black N/2), indicative of products of bacterial sulfate reduction, occurs commonly between 181.1 and 219.7 mbsf, and this had been absent since 102 mbsf. This suggests that the measured levels of sulfate could have been real. Additionally, it is difficult to account for such consistent increases in total bacterial and DDC numbers to levels not encountered since $50 \mathrm{mbsf}$ by contamination (Parkes et al., 1990). Similar increases in bacterial numbers at great sediment depth that are associated with increases in sulfate or methane concentrations have been observed at other ODP sites (Cragg et al., 1990, 1995b; Parkes et al., 1990).

\section{General}

These data represent the first deep sediment samples taken for bacterial analysis from the Atlantic Ocean. Previous work from six ODP legs in the Pacific Ocean has yielded an exponential relationship of bacterial populations with sediment depth (Parkes et al., 1994), and bacterial profiles in Amazon Fan sediments are consistent with this data (Fig. 5). This supports the contention that such bacterial/depth relationships are ubiquitous despite widely differing oceanic settings (Parkes et al., 1994).

The topmost parts of Holes 934A and 940A consist of intensely bioturbated foraminifer-nanofossil clay of Holocene age. These layers are small, $0.87 \mathrm{~m}$ and $0.24 \mathrm{~m}$ in Holes 934A and 940A, respectively, and represent a period of time when the fan has not been active, thus preventing significant terrigenous input to the sediments. In these conditions the near-surface bacterial populations can be directly compared with those from other sites (Table 1). Data from the Amazon Fan occupy a position commensurate with the depth of the over- lying water, being greater than near-surface bacterial populations from deeper and less productive sites, not significantly different than those from similar water depths and productivities, and markedly lower than those from much shallower and more productive sites. Correlation analysis produced a highly significant relationship between overlying water depth and sediment near-surface bacterial population size $(R=0.841 ; N=9 ; P<0.01)$.

\section{SUMMARY}

This data set represents the first bacterial analysis of deep sediments from the Atlantic Ocean and from a river fan-system. Bacterial populations decline with sediment depth at a rate similar to that previously observed in Pacific Ocean sediments. However, in these sediments, it is apparent that changes in sedimentary input strongly influence both the bacterial profile and sediment geochemistry. Areas of rapid, small turbidites coupled with bioturbation, and areas of massive mud flows or slumps were generally associated with unusually constant depth profiles. Conversely, where such activity was low and sedimentary input was more depositional, the expected gradual decreases in bacterial populations with depth were observed. Overall organic carbon concentrations were low, but where significant amounts of plant material were buried this coincided with highly significant increases in bacterial populations. A strong trend of population increase in both total count and DDC toward the base of Hole 940A was difficult to explain. It was associated with rises in sulfate and methane concentrations, situations previously associated with elevated bacterial populations at depth (Parkes et al., 1990, 1994). Shipboard geochemists, however, consider these to be due to drilling contamination. Nevertheless, the unexpected presence of black color banding, together with the resilience of the direct count technique to contamination, suggests that the bacterial population increase is indeed real and that some sulfate reduction may have occurred at these depths. 
Table 1. Comparison of Amazon Fan total bacterial populations in nearsurface sediments with those from ODP sites in the Pacific Ocean.

\begin{tabular}{lccc}
\hline \multicolumn{1}{c}{ Source } & Leg & $\begin{array}{c}\text { Water } \\
\text { depth } \\
(\mathrm{m})\end{array}$ & $\begin{array}{l}\text { Direct count } \\
(\text { cells/cm }\end{array}$ \\
\hline Peru Margin & 112 & 150 & $3.30 \times 10^{9}$ \\
Santa Barbara Basin & 146 & 576 & $1.27 \times 10^{9}$ \\
Japan Sea & 128 & 900 & $7.82 \times 10^{8}$ \\
Cascadia Margin (Oregon) & 146 & 1326 & $6.95 \times 10^{8}$ \\
Cascadia Margin (Vancouver) & 146 & 2516 & $5.32 \times 10^{8}$ \\
Lau Basin & 135 & 2692 & $6.12 \times 10^{8}$ \\
Amazon Fan (Site 940) & 155 & 3195 & $5.62 \times 10^{8}$ \\
Amazon Fan (Site 934) & 155 & 3432 & $6.04 \times 10^{8}$ \\
Eastern Equatorial Pacific & 138 & 3761 & $2.08 \times 10^{8}$ \\
\hline
\end{tabular}

Notes: $*=$ calculated bacterial count over top $5 \mathrm{~cm}$ of sediment. Depth data from Suess, von Huene, et al. (1988; ODP Leg 112, Site 681); Ingle, Suyehiro, von Breymann, et al. (1990; ODP Leg 128, Site 798); Parson, Hawkins, Allan, et al. (1992; ODP Leg 135, Site 834); Mayer, Pisias, Janecek, et al. (1992; ODP Leg 138, Site 851), Westbrook, Carson, Musgrave, et al. (1994; ODP Leg 146(1), Sites 888/890); and Kennett, Baldauf, et al. (1994 ODP Leg 146(2), Site 893 [Santa Barbara]). Bacterial data from Parkes et al. (1993; Charles Darwin Cruise Leg 38); Cragg et al. (1992; ODP Leg 128); Cragg (1994; ODP Leg 135); Cragg and Kemp (1995; ODP Leg 138); and Cragg et al. (1995a, 1995b; ODP Leg 146 Pts. 1 and 2).

\section{ACKNOWLEDGMENTS}

We thank ODP for allowing us to obtain samples during Leg 155 and specifically shipboard scientist Ralph Schneider who was involved with actual sample collection. We thank John C. Fry and an anonymous referee for their useful comments and criticisms on this manuscript. This work was funded by Natural Environment Research Council (U.K.) grant GST/02/683.

\section{REFERENCES}

Cragg, B.A., 1994. Bacterial profiles in deep sediment layers from the Lau Basin (Site 834). In Hawkins, J., Parson, L., Allan, J., et al., Proc. ODP, Sci. Results, 135: College Station, TX (Ocean Drilling Program), 147150

Cragg, B.A., Harvey, S.M., Fry, J.C., Herbert, R.A., and Parkes, R.J., 1992. Bacterial biomass and activity in the deep sediment layers of the Japan Sea, Hole 798B. In Pisciotto, K.A., Ingle, J.C., Jr., von Breymann, M.T., Barron, J., et al., Proc. ODP, Sci. Results., 127/128 (Pt. 1): College Station, TX (Ocean Drilling Program), 761-776.

Cragg, B.A., and Kemp, A.E.S., 1995. Bacterial profiles in deep sediment layers from the Eastern Equatorial Pacific Ocean, Site 851. In Pisias, N.G., Mayer, L.A., Janecek, T.R., Palmer-Julson, A., and van Andel, T.H. (Eds.), Proc. ODP, Sci. Results, 138: College Station, TX (Ocean Drilling Program), 599-604.

Cragg, B.A., and Parkes, R.J., 1994. Bacterial profiles in hydrothermally active deep sediment layers from Middle Valley (NE Pacific), Sites 857 and 858. In Mottl, M.J., Davis, E.E., Fisher, A.T., and Slack, J.F. (Eds.), Proc. ODP, Sci. Results, 139: College Station, TX (Ocean Drilling Program), 509-516.

Cragg, B.A., Parkes, R.J., Fry, J.C., Herbert, R.A., Wimpenny, J.W.T., and Getliff, J.M., 1990. Bacterial biomass and activity profiles within deep sediment layers. In Suess, E., von Huene, R., et al., Proc. ODP, Sci. Results, 112: College Station, TX (Ocean Drilling Program), 607-619.

Cragg, B.A., Parkes, R.J., Fry, J.C., Weightman, A.J., Maxwell, J.R., Kastner, M., Hovland, M., Whiticar, M.J., Sample, J.C., and Stein, R., 1995a. Bacterial profiles in deep sediments of the Santa Barbara Basin, Site 893. In Kennett, J.P., Baldauf, J.G., and Lyle, M. (Eds.), Proc. ODP, Sci. Results, 146 (Pt. 2): College Station, TX (Ocean Drilling Program), 139144.

Cragg, B.A., Parkes, R.J., Fry, J.C., Weightman, A.J., Rochelle, P.A., and Maxwell, J.R., 1996. Bacterial populations and processes in sediments containing gas hydrates (ODP Leg 146: Cascadia margin). Earth Planet. Sci. Lett, 139:497-507.
Cragg, B.A., Parkes, R.J., Fry J.C., Weightman, A.J., Rochelle, P.A., Maxwell, J.R., Kastner, M., Hovland, M., Whiticar, M.J., and Sample, J.C., 1995b. The impact of fluid and gas venting on bacterial populations and processes in sediments from the Cascadia Margin accretionary system (Sites 888-892) and the geochemical consequences. In Carson, B., Westbrook, G.K., Musgrave, R.J., and Suess, E. (Eds.), Proc. ODP, Sci. Results, 146 (Pt. 1): College Station, TX (Ocean Drilling Program), 399411.

Damuth, J.E., and Flood, R.D., 1984. Morphology, sedimentation processes, and growth pattern on the Amazon deep-sea fan. Geo-Mar. Lett., 3:109117.

, 1985. Amazon fan, Atlantic Ocean. In Bouma, A.H., Normark, W.R., and Barnes, N.E. (Eds.), Submarine Fans and Related Turbidite Systems: New York (Springer), 97-106.

Damuth, J.E., and Kumar, N., 1975. Amazon Cone: morphology, sediments, age, and growth pattern. Geol. Soc. Am. Bull., 86:863-878.

Damuth, J.E., Flood, R.D., Knowsmann, R.O., Belderson, R.H., Gorini, M.A., 1988. Anatomy and growth patterns of Amazon deep-sea fan as revealed by long-range side-scan sonar (GLORIA) and high-resolution seismic studies. AAPG Bull., 72:885:911.

Flood, R.D., Piper, D.J.W., and Shipboard Scientific Party, 1995. Introduction. In Flood, R.D., Piper, D.J.W., Klaus, A., et al., Proc. ODP, Init. Repts., 155: College Station, TX (Ocean Drilling Program), 5-16.

Flood, R.D., Piper, D.J.W., Klaus, A., et al., 1995. Proc. ODP, Init. Repts., 155: College Station, TX (Ocean Drilling Program).

Fry, J.C., 1988. Determination of biomass. In Austin, B. (Ed.), Methods in Aquatic Bacteriology: Chichester (Wiley), 27-72.

Getliff, J.M., Fry, J.C., Cragg, B.A., and Parkes, R.J., 1992. The potential for bacteria growth in deep sediment layers of the Japan Sea, Hole 798BLeg 128. In Pisciotto, K.A., Ingle, J.C., Jr., von Breymann, M.T., Barron, J., et al., Proc. ODP, Sci. Results, 127/128 (Pt. 1): College Station, TX (Ocean Drilling Program), 755-760.

Goulder, R., 1977. Attached and free bacteria in an estuary with abundant suspended solids. J. Appl. Bacteriol., 43:399-405.

Huber, R., Kurr, M., Jannasch, H.W., and Stetter, K.O., 1989. A novel group of abyssal methanogenic archaebacteria (Methanopyrus) growing at $110^{\circ} \mathrm{C}$. Nature, $342: 833-834$.

Ingle, J.C., Jr., Suyehiro, K., von Breymann, M.T., et al., 1990. Proc. ODP, Init. Repts., 128: College Station, TX (Ocean Drilling Program).

Jørgensen, B.B., Bang, M., Blackburn, T.H., 1990. Anaerobic mineralization in marine sediments from the Baltic Sea-North Sea transition. Mar. Ecol. Prog. Ser., 59:39-54.

Jørgensen, B.B., Isaksen, M.F., and Jannasch, H.W., 1992. Bacterial sulfate reduction above $100^{\circ} \mathrm{C}$ in deep-sea hydrothermal vent sediments. Science, 258:1756-1757.

Kastner, M., Elderfield, H., and Martin, J.B., 1991. Fluids in convergent margins: what do we know about their composition, origin, role in diagenesis and importance for oceanic chemical fluxes? Philos. Trans. R. Soc. London A, 335:243-259.

Kennett, J.P., Baldauf, J.G., et al., 1994. Proc. ODP, Init. Repts., 146 (Pt. 2): College Station, TX (Ocean Drilling Program).

Kirchman, D., Sigda, J., Kapuscinski, R., and Mitchell, R., 1982. Statistical analysis of the direct count method for enumerating bacteria. Appl. Environ. Microbiol., 44:376-382.

Krumbein, W.E., 1983. Microbial Geochemistry: Oxford (Blackwell).

Kvenvolden, K.A., and Kastner, M., 1990. Gas hydrates of the Peruvian outer continental margin. In Suess, E., von Huene, R., et al., Proc. ODP, Sci. Results, 112: College Station, TX (Ocean Drilling Program), 517526.

Manley, P.L., and Flood, R.D., 1988. Cyclic sediment deposition within the Amazon deep-sea fan. AAPG Bull., 72:912-925.

Mayer, L., Pisias, N., Janecek, T., et al., 1992. Proc. ODP, Init. Repts., 138 (Pts. 1 and 2): College Station, TX (Ocean Drilling Program).

Parkes, R.J., Cragg, B.A., Bale, S.J., and Fry, J.C., 1995. A combined ecological and physiological approach to studying sulphate reduction within deep marine sediment layers. J. Microbiol. Methods, 23:235-249.

Parkes, R.J., Cragg, B.A., Bale, S.J., Getliff, J.M., Goodman, K., Rochelle, P.A., Fry, J.C., Weightman, A.J., and Harvey, S.M., 1994. A deep bacterial biosphere in Pacific Ocean sediments. Nature, 371:410-413.

Parkes, R.J., Cragg, B.A., Fry, J.C., Herbert, R.A., and Wimpenny, J.W.T., 1990. Bacterial biomass and activity in deep sediment layers from the Peru margin. Philos. Trans. R. Soc. London A, 331:139-153. 
Parkes, R.J., Cragg, B.A., Getliff, J.M., Harvey, S.M., Fry, J.C., Lewis, C.A., and Rowland, S.J., 1993. A quantitative study of microbial decomposition of biopolymers in Recent sediments from the Peru Margin. Mar. Geol., 113:55-66.

Parson, L., Hawkins, J., Allan, J., et al., 1992. Proc. ODP, Init. Repts., 135: College Station, TX (Ocean Drilling Program).

Pledger, R.J., and Baross, J.A., 1991. Preliminary description and nutritional characterization of a heterotrophic archaeobacterium growing at temperatures of up to $110^{\circ} \mathrm{C}$ isolated from a submarine hydrothermal vent environment. J. Gen. Microbiol., 137:203-211.

Schimmelmann, A., Lange, C.B., and Berger, W.H., 1990. Climatically controlled marker layers in Santa Barbara basin sediments, and fine-scale core-to-core correlation. Limnol. Oceanogr., 35:165-173.

Suess, E., von Huene, R., et al., 1988. Proc. ODP, Init. Repts., 112: College Station, TX (Ocean Drilling Program).

Suess, E., and Whiticar, M.J., 1989. Methane-derived $\mathrm{CO}_{2}$ in pore fluids expelled from the Oregon subduction zone. Palaeogeogr., Palaeoclimatol., Palaeoecol., 71:119-136.
Tarafa, M.E., Whelan, J.K., Oremland, R.S., and Smith, R.L., 1987. Evidence of microbiological activity in Leg 95 (New Jersey Transect) sediments. In Poag, C.W., Watts, A.B., et al., Init. Repts. DSDP, 95: Washington (U.S. Govt. Printing Office), 635-640.

Westbrook, G.K., Carson, B., Musgrave, R.J., et al., 1994. Proc. ODP, Init. Repts., 146 (Pt. 1): College Station, TX (Ocean Drilling Program).

Whelan, J.K., Oremland, R., Tarafa, M., Smith, R., Howarth, R., and Lee, C., 1986. Evidence for sulfate-reducing and methane producing microorganisms in sediments from Sites 618, 619, and 622. In Bouma, A.H., Coleman, J.M., Meyer, A.W., et al., Init. Repts. DSDP, 96: Washington (U.S. Govt. Printing Office), 767-775.

Date of initial receipt: 16 January 1996

Date of acceptance: 18 April 1996

Ms 155SR-229 